\title{
Morphological, Anatomical and Proximate Properties of Ageratum conyzoides Linn A Member of Asteraceae
}

\author{
Wahua $\mathrm{C}^{1 *}$, Nwuzi BC ${ }^{1}$
}

${ }^{1}$ Plant Science and Biotechnology, Faculty of Science, University of Port Harcourt, P.M.B. 5323, Port Harcourt, Nigeria

DOI: $10.36347 / \mathrm{sajb} .2021 . v 09 i 03.002$

| Received: 07.02.2021 | Accepted: 09.03.2021 | Published: 20.03.2021

*Corresponding author: Wahua C

Abstract

Original Research Article

Ageratum conyzoides is a common weed of the Niger Delta tropical and semi tropical regions useful in tradomedicine. This research investigated the taxonomic characteristics of the plant. The stem is erect, sometimes prostrate, branched and hairy. The petiolate leaves are simple ovate with opposite phyllotaxy having serrated margins measuring up to $10 \pm 2 \mathrm{~cm}$ long and $7 \pm 2 \mathrm{~cm}$ wide, growing to $80 \pm 15 \mathrm{~cm}$ in height, with an acute apex. The inflorescence is terminal axillary cluster with whitish to pale bluish tubular florets. Epidermal study revealed anomocytic stomata which is amphistomatic in nature. Anatomical study showed a layer of epidermal cells. The hypodermis is made of 2 to 3 rolls of collenchyma, general cortex and pith dominated by parenchyma in the same pattern of occurrence in mid-ribs, petioles, stems, nodes and roots except that the number of rolls of cells varied slightly and vasculation is open type. There are presence of crystals and tanniferous cells. Proximate investigation revealed $81.45 \pm 0.12 \%$ moisture, $0.65 \pm 0.2 \%$ ash, $3.70 \pm 0.11 \%$ lipid, $4.42 \pm 0.04 \%$ proteins, $3.10 \pm 0.09 \%$ carbohydrate and $6.68 \pm 0.01 \%$ fiber respectively. The information generated here would further assist in the delimitation of the species.

Keywords: Chemotaxonomy, Ageratum, weeds, flowers. Anatomy, Proximate.

Copyright $\left({ }_{0} 2021\right.$ The Author(s): This is an open-access article distributed under the terms of the Creative Commons Attribution 4.0 International License (CC BY-NC 4.0) which permits unrestricted use, distribution, and reproduction in any medium for non-commercial use provided the original author and source are credited.

\section{INTRODUCTION}

Ageratum conyzoides belongs to Asteraceae, commonly referred as billy goat weed [1] Asteraceae is made of about 25,000 species belonging to about 1,500 genera [2]. Ageratum conyzoides is common in western and eastern parts of African, regions of Asia and South America [3, 4]. In the family Asteraceae, there exist considerable anatomical diversity which is as a result of their ecological specialization and these features manifest in their occurrence in diverse habitats as in presence of secretory structures, varying vascular bundles, secretory cells directly associated with the phloem, are of great taxonomical interest and their restricted distribution has an important diagnostic value $[5-8,9]$ mentioned differences in their mid-rib shape used to classify members of the family. There are presence of non-glandular trichomes [10, 11]. The differentiation of trichomes is genetically controlled and their frequency affected by environmental factors, both abiotic and biotic components [12]. Anatomically, the midrib of $A$. conyzoides has single trace of vascular bundle, 4-5 layers of abaxial and 6-7 layers adaxial parenchymatous cells and the midrib elevated to form an obtuse angle at the apex [9]. This varied from one ecozone to another within the cardinal regions of Rivers State.

Thus justification is to add more information to existing knowledge on the comparative taxonomic characteristics of the plant, and the objectives focused on the micro- and macro-morphological, anatomical and proximate properties of Ageratum conyzoides Linn.

\section{MATERIALS AND METHODS Geographic Location}

The location of the parent plant studied was Port Harcourt, Rivers, Nigeria.

\section{Morphological Studies}

The meter rule was used to confirm the plant height, leaf length and width etc.

\section{Micro-morphological (Epidermal) Studies}

Fresh leaves and young stem collected for this study were peeled and subjected to alcohol solutions in the ratio of $50 \%, 75 \%$ and absolute alcohol respectively. The cleared epidermal layers obtained were stained with safranin for 5 minutes washed and counter stained with Alcian blue for same time interval, washed and temporarily mounted in aqueous glycerol solution. 
Photomicrographs were taken from good preparations. The stomatal index (S.I.) was obtained using the formula:

$$
\text { S. I. }=\frac{S}{S+E} \quad X \frac{100}{1}
$$

Where $S$ and $E$ are mean numbers of stomata and epidermal cells respectively within the particular area under investigation. Likewise trichome Index (T.I) was obtained using:

$$
\text { T. I. }=\frac{T}{T+E} \quad X \frac{100}{1}
$$

Where $\mathrm{T}$ and $\mathrm{E}$ are trichomes and epidermal cells respectively within the study area.

\section{ANATOMICAL STUDY}

The plant was harvested from the wild for the secondary anatomy. The harvested stems, leaves, petioles, flowers, fruits and roots were dehydrated in alcohol solutions of $50 \%, 75 \%$, absolute alcohol and thereafter subjected through alcohol chloroform series in the ratio of 3:1 of alcohol chloroform series, 1:1, 1:3 and pure chloroform respectively for five minutes in each. Then rehydrated following same procedure to $50 \%$ alcohol before staining with safranin for 2 to 5 minutes, counter stained with Alcian blue for same time interval. Free hand section was done using a systematic

$$
\% \text { Organic Nitrogen }=
$$

Stage 3: The distillate was titrated with standard $0.1 \mathrm{~N} \mathrm{HCl}$ solution back to purple from greenish. The volume of $\mathrm{HCl}$ added to effect this change was recorded as titre value. Thus,

Where $1.4=$ Nitrogen equivalent to the normality of $\mathrm{HCl}$ used in the titration, $0.1 \mathrm{~N}$

$100=$ the total volume of digest dilution.

$100=$ percentage factor.

$0.1 \mathrm{~g}$ of the sample

$1000=$ conversion from gram to milligram

$20=$ Integral volume of digits analyzed or distilled

$0.1=$ the weight of sample in gram digested

Carbohydrate (Cleg Anthrone Method) arrangement of 5 razor blades as described by [13] was also adopted. Microphotographs were taken from good preparations using Sony camera of 7.2 Mega pixels having 2.411 LCD monitor and High sensitivity ISO 1250 .

\section{PROXIMATE PROPERTIES}

Proximate properties were done following the methods of [14].

Proteins (Kjeldahl method)

Stage 1: $0.1 \mathrm{~g}$ of sample was weighed into a clean conical flask $250 \mathrm{ml}$ capacity, $3 \mathrm{~g}$ of digestion catalyst was introduced into the flask and $20 \mathrm{ml}$ conc. Sulphuric acid added and heated to digest. Color change from black to sky-blue cooled to room temperature and then diluted to $100 \mathrm{ml}$ with distilled water.

Stage 2: $20 \mathrm{ml}$ diluted digest was measured into a distillation flask and held in place on hot plate. The distillation flask was attached to a Liebig condenser connected to a receiver containing $10 \mathrm{ml}$ of $2 \%$ boric acid indicator. $40 \mathrm{ml} \mathrm{NaOH}$ was injected into the digest which became strongly alkaline, and heated to boiling and the distilled ammonia gas via the condenser into the receiver beaker. The color of the boric acid change from purple to green as ammonia distillate was introduced into the boric acid.
$1000 \times 20 \times 0.1$

$0.1 \mathrm{~g}$ of the sample was weighed into a $25 \mathrm{ml}$ volumetric flask, $1 \mathrm{ml}$ distilled water and $1.3 \mathrm{ml}$ of $62 \%$ perchloric acid was added and stirred for a period of 20 minutes to homogenize completely. The flask was made up to $25 \mathrm{ml}$ mark with distilled water. The solution formed was filtered through a glass filter paper or allowed to sediment and decanted. $1 \mathrm{ml}$ of the filtrate was collected and transferred into a $10 \mathrm{ml}$ test tube which was diluted to volume with distilled water. $1 \mathrm{ml}$ of working solution was pipette into a clean test tube and $5 \mathrm{ml}$ anthrone reagent was added. $1 \mathrm{ml}$ distilled water was added and $5 \mathrm{ml}$ anthrone reagent mixed. Similarly, the whole mixture read at $630 \mathrm{~nm}$ wavelength using the $1 \mathrm{ml}$ distilled water and the $5 \mathrm{ml}$ anthrone reagent prepared as blank. $0.1 \mathrm{ml}$ glucose was also prepared and was treated as the sample with anthrone reagent.

$$
\% \mathrm{CHO} \text { as glucose }=\frac{25 \mathrm{x} \text { absorbance of sample }}{\text { Absorbance of standard glucose } \mathrm{x} 1}
$$

Absorbance of the standard glucose was read and the value of carbohydrate as glucose was calculated as shown below:

\section{Moisture (Air Oven Method)}

$1 \mathrm{~g}$ of the sample was weighed into a clean dried porcelain evaporating dish. This was placed in an oven set at $105^{\circ} \mathrm{C}$ for 6 hours. The evaporating dish was 
cooled in the desiccator to room temperature and reweighed. Thus the calculation of $\%$ moisture was as shown below:

$$
\% \text { Moisture }=\frac{\text { Weight of fresh sample }- \text { Weight of dried sample }}{\text { Weight of sample used }} \quad X \frac{100}{1}
$$

\section{Lipid (Soxhlet Extraction Method)}

$2 \mathrm{~g}$ of sample was inserted into a filter paper and was placed into a soxhlet extractor. The extractor was placed into a pre-weighed dried distillation flask. Then the solvent (acetone) was introduced into the distillation flask via the condenser end attached to the soxhlet extractor. The set-up was held in place with a restored stand clamp, cooled water jet was allowed to flow into the condenser and the heated solvent was refluxed as a result. The lipid in the solvent chamber was extracted in the process of continuous refluxing. When the lipid was observably extracted completely from the sample, the condenser and the extractor were disconnected and the solvent was evaporated to concentrate the lipid. The flask was then dried in the air oven to constant weight and re-weighed to obtain the weight of the lipid as thus calculated below:

$$
\% \text { Lipid }=\frac{\text { Weight of flask and extract }- \text { Weight of empty flask }}{\text { Weight of sample extracted }} \quad X \frac{100}{1}
$$

\section{Ash (Furnace Method)}

$1 \mathrm{~g}$ of the dried sample was weighed into porcelain crucible which was previously preheated and weighed. The crucible was inserted into a muffle furnace set at $630^{\circ} \mathrm{C}$ for 3 hours and allowed to cool to room temperature and reweighed. Thus $\%$ ash was calculated as shown below:

$$
\% \text { Ash }=\frac{\text { Weight of crucible }+ \text { Ash sample }- \text { Weight of crucible }}{\text { Weight of sample }} \quad X \frac{100}{1}
$$

\section{Crude Fibre}

Crude fibre represents the insoluble, combustible organic residue which remained after a sample has been treated with light petroleum ether, dilute acid and alkali [14].

About $2 \mathrm{~g}$ of sample was extracted with petroleum ether $\left(\mathrm{W}_{1}\right)$. Sample was boiled under reflux for 30 minutes with $200 \mathrm{ml}$ of dilute $\mathrm{HCl}$ and filtered. The residue was thoroughly washed with water until acid-free. The residue was transferred into a beaker and boiled for about 30 minutes with $200 \mathrm{ml}$ of dilute $\mathrm{NaOH}$ solution, filtered and transferred into ignition crucible. The residue was washed 3 times with $20 \mathrm{ml}$ ethanol and 2 times with $10 \mathrm{ml}$ ether. The residue dried in an oven and cooled and weighed $\left(\mathrm{W}_{2}\right)$. The dried residue was transferred into a furnace and ignited, cooled and weighed $\left(\mathrm{W}_{3}\right)$. Thus \%crude fibre was calculated as shown below:

$$
\% \text { Crude Fibre }=\frac{\mathrm{W}_{2}-\mathrm{W}_{3}}{\mathrm{~W}_{1}} \times \frac{100}{1}
$$

\section{RESULT}

\section{Geographic Location Parent Plants}

The geographic location of the parent plant was found and harvested in Community Primary School Choba, Obio-Akpor Local Government Area of Rivers State, Nigeria.

\section{MORPHOLOGICAL STUDY}

The morphological feature of Ageratum conyzoides Linn. revealed whitish to pale bluish flower florets. The stem is erect, sometimes prostrate, branched and hairy. The petiolate leaves are simple ovate with opposite phyllotaxy having serrated margins measuring up to $10 \pm 2 \mathrm{~cm}$ long and $7 \pm 2 \mathrm{~cm}$ wide, growing to $80 \pm 15 \mathrm{~cm}$ in height, both have acute apex. The inflorescence has terminal axillary clusters and florets are tubular in shape Plate-1. 


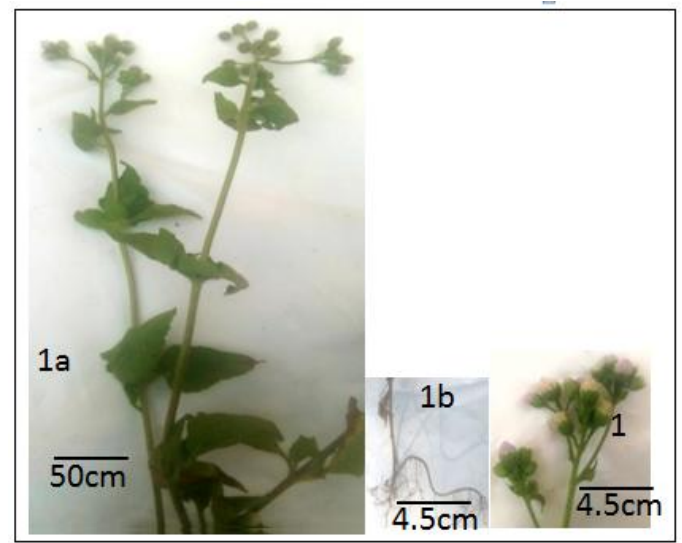

Plate-1: Ageratum conyzoides Linn. 1b and 1c: Tap root system and flower inflorescence of $A$. conyzoides

\section{Epidermal Study}

Epidermal study revealed anomocytic stomata which is amphistomatic in nature. Anatomical study showed a layer of epidermal cells Plates 2 and 3.

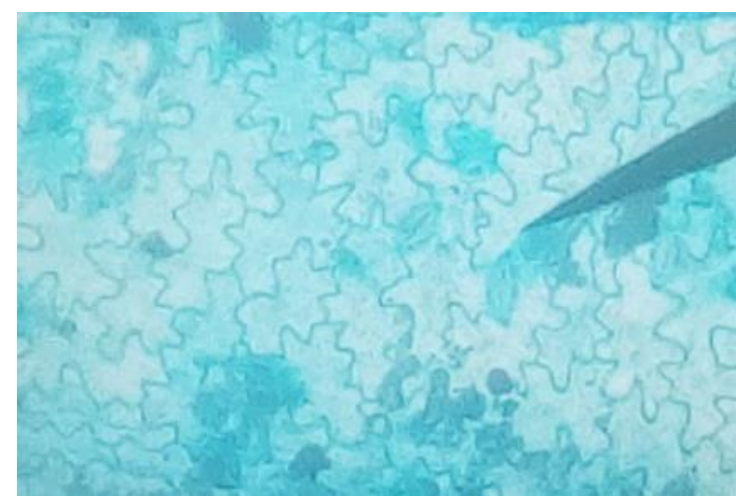

Plate 2: A. conyzoides abaxial foliar surface

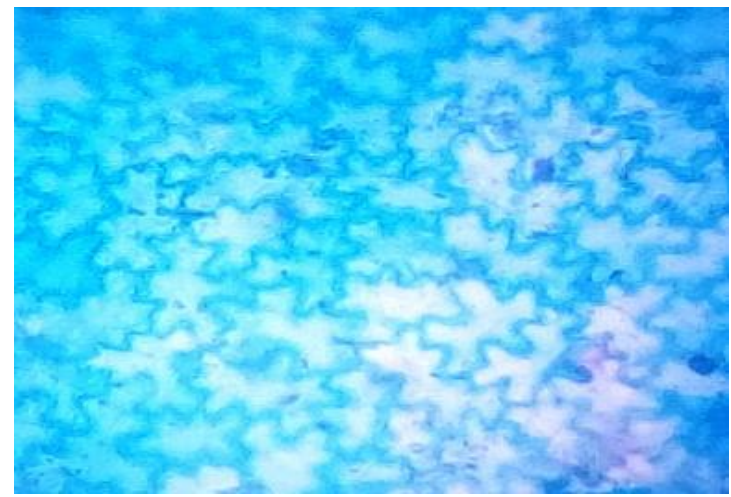

Plate 3: A. conyzoides adaxial foliar surface

There are more stomata at the abaxial foliar epidermis than as observed in the adaxial layer while more oil glands or secretory structures on the adaxial surface.

\section{Anatomical Study}

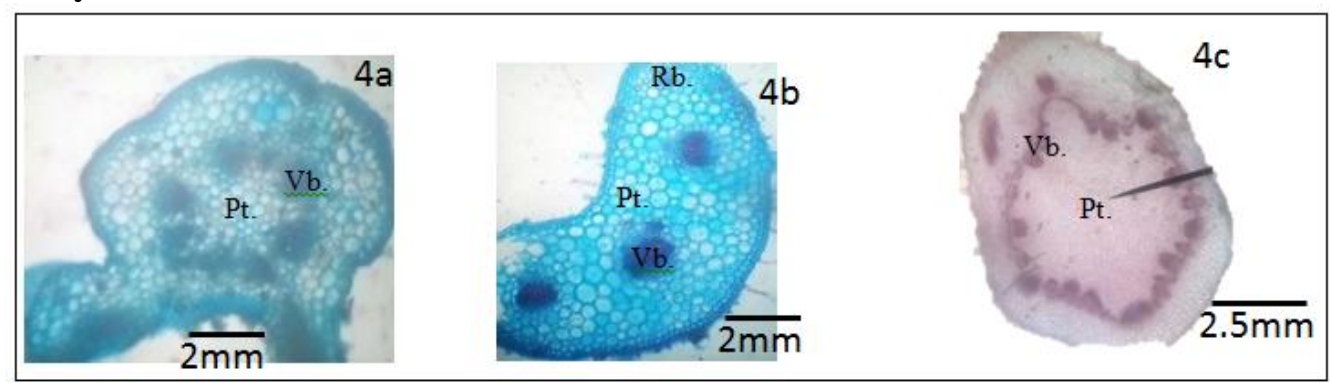

Fig-4: Anatomy of Ageratum conyzoides. 4a: Mid-rib, 4b: Petiole, 4c: Node

Key: Pt. represents Pith; Vb. is Vascular bundle, Xy. stands for Xylem, Ph. are Phloem, while Rb. is Bundle wing

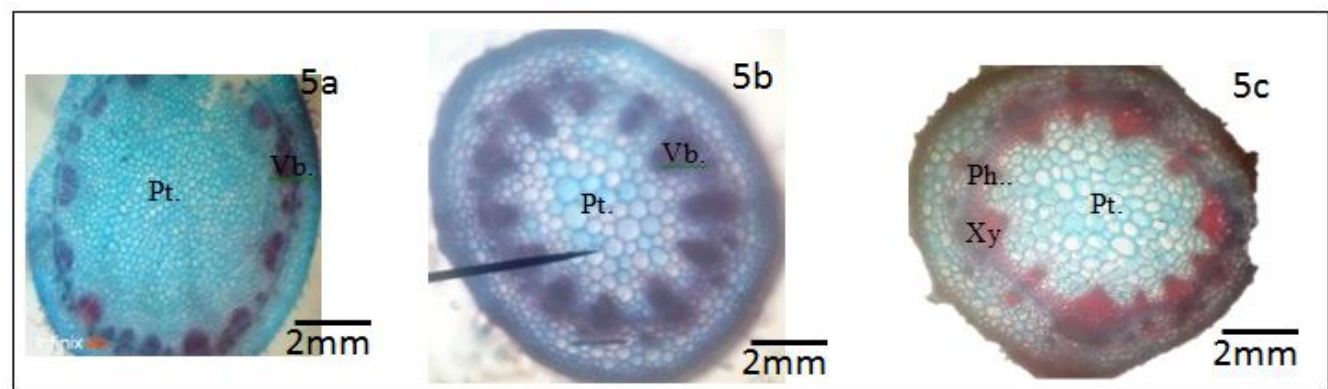

Fig-5: Anatomy of Ageratum conyzoides. 5a: Stem, 5b: Stem-root transition zone, 5c: Root.

Key: Pt. represents Pith; Vb. is Vascular bundle, Xy. stands for Xylem, Ph. are Phloem, while Rb. is Bundle wing 
The hypodermis is made of collenchyma, general cortex and pith dominated by parenchyma in the same pattern of occurrence in mid-ribs, petioles, stems, nodes and roots and vasculation is open type Plates $4 \mathrm{a}$, $4 \mathrm{~b}, 4 \mathrm{c}, 5 \mathrm{a}, 5 \mathrm{~b}$ and $5 \mathrm{c}$.

The epidermis has uniseriate trichomes and made of a single layer of cells. Directly below the epidermis is the hypodermis made of 2 to 3 layers of collenchyma, the general cortex and pith consist of parenchyma. The central region of the pith has larger parenchymatous cells. The general cortex is predominated by 3 to 4 rolls of cells in mid-rib, stems and roots while in petiole and node there are 4 to 5 rolls of cells.

Table-1: Proximate Properties of Ageratum conyzoides Linn

\begin{tabular}{|l|l|l|l|l|l|l|}
\hline Plant & \%Proteins & \% Carbohydrate & \%Lipid & \% Moisture & \%Fibre & \%Ash \\
\hline Ageratum conyzoides Linn. & $4.42 \pm 0.04$ & $3.10 \pm 0.09$ & $3.70 \pm 0.11$ & $81.45 \pm 0.12$ & $6.68 \pm 0.01$ & $0.65 \pm 0.2$ \\
\hline
\end{tabular}

\section{DISCUSSION}

Observation of secretory structures in mid-ribs, petioles and stem which agrees to the work done by [5-8]. There are presence of non-glandular trichomes as also revealed by $[10,11]$. The mid-ribs at secondary growth is not arc, but surrounded the pith in the form of a circle made of about 7 to 8 vascular bundles which concorded with the work of [9]. The petiole observed with 3 traces of vascular bundles and a pair of rib bundle wings. It has $6.68 \pm 0.01 \%$ fibre which could be useful to remedy indigestion as dietary fibre.

\section{CONCLUSION}

Ageratum conyzoides Linn. is useful in tradomedicine. Karyotypes, quantitative aspect of phytochemistry and DNA barcodes may be essential area of future interest.

\section{REFERENCES}

1. Stone BC. The Flora of Guam Micronosica. 1970; 6:1-659.

2. Souza VC, Lorenzi H. Botânica sistemática: guia ilustrado para identificação das famílias de fanerógamas nativas e exóticas no Brasil, baseado em APG III. Instituto Plantarum, Nova Odessa. 2012.

3. Bhatt JR, Singh JS, Singh SP, Tripathi RS, Kohli RK. Invasive Alien Plants: An Ecological Appraisal for the Indian Subcontinent. Cabi, Wallingford, UK. 2012.

4. Iwu MM. Handbook of Africa Medicinal Plants, 2nd ed. CRC Press, New York. 2014.

5. Metcalfe CR, Chalk L. Anatomy of the Dicotyledons: Leaves, Stem and Wood in Relation to Taxonomy With notes on Economic uses. The Clarendon Press, Virginia. 1950

6. Fahn A. Secretory Tissues in Plants. Academic Press, New York. 1979.

7. Solereder H. Systematic anatomy of the Dicotyledons. Claredon Press, Oxford. 1908.

8. Makbul S, Coskuncelebi K, Türkmen ZA, Beyazoglu O. Comparison of foliar anatomy of Scorzonera L.(Asteraceae) taxa from northeast Anatolia. Pakistan Journal of Botany. 2011 Feb 1;43(1):135-55.

9. Ekeke C, Mensah SI. Comparative Anatomy of Midrib and its Significance in the Taxonomy of the Family Asteraceae from Nigeria. Journal of Plant Sciences, 2016;10: 200-205.

10. Folorunso AE, Awosode OD. Comparative anatomy of invasive and non-invasive species in the family Asteraceae in Nigeria. International Journal of Biological and Chemical Sciences. 2013;7(5):1804-19.

11. Rahman AH, Islam AK, Rahman MM. An anatomical investigation on Asteraceae family at Rajshahi Division, Bangladesh. Int $\mathrm{J}$ Biosci. 2013;3(1):13-23.

12. Werker E. Trichome diversity and development. In: Hallahan, DL, Gray JC. (Eds.), Advances in Botanical Research: Plant Trichomes. Academic Press, San Diego, 2000;1-35.

13. Wahua C. Free-hand Sectioning Machine Invented for Anatomical Studies of Biological Materials. Scientia Africana, 2020;19(1):159-162.

14. AOAC. Official Methods of Analysis $14^{\text {th }}$ Ed., Arlington, and CA. sees 1984;7.025-7.032. 